IRA-International Journal of Education \&

Multidisciplinary Studies

ISSN 2455-2526; Vol.17, Issue o3 (Q3, 2021)

Pg. no. 197-202.

IRA Academico Research

\title{
Hysterical Screaming \& Cruel Reality-A Study of The Story of An Hour from the perspective of Peirce's Semiotic Theory
}

\author{
Jiayi Zheng (ic) \\ School of Foreign Studies, University of Science and Technology Beijing, China.
}

Type of Work: Peer Reviewed.

DOI: 10.21013/jems.v17.n3.p11

DOI URL: https://dx.doi.org/10.21013/jems.v17.n3.p11

\section{How to cite this paper:}

Zheng, J. (2021). Hysterical Screaming \& Cruel Reality-A Study of The Story of An Hour from the perspective of Peirce's Semiotic Theory. IRA-International Journal of Education \& Multidisciplinary Studies (ISSN 2455-2526), 17(3), 197-202. DOl: https://dx.doi.org/10.21013/jems.v17.n3.p11

(C) IRA Academico Research.

(oc) EY-NG This work is licensed under a Creative Commons Attribution-NonCommercial 4.0 International License subject to a proper citation to the publication source of the work.

Disclaimer: The scholarly papers as reviewed and published by IRA Academico Research are the views and opinions of their respective authors and are not the views or opinions of IRA Academico Research. IRA Academico Research disclaims any harm or loss caused due to the published content to any party.

IRA Academico Research is an institutional publisher member of Publishers International Linking Association Inc. (PILA-CrossRef), USA. IRA Academico Research is an institutional signatory to the Budapest Open Access Initiative. Hungary advocating the open access of scientific and scholarly knowledge. IRA Academico Research is a registered content provider under Open Access Initiative Protocol for Metadata Harvesting (OAI-PMH).

The journal is indexed \& included in WorldCat Discovery Service (USA), CrossRef Metadata Search (USA), WorldCat (USA), OCLC (USA), Open J-Gate (India), EZB (Germany) Scilit (Switzerland), Airiti (China), Bielefeld Academic Search Engine (BASE) of Bielefeld University, Germany, PKP Index of Simon Fraser University, Canada.

Jiayi Zheng (D)/0000-0002-8462-3680 


\begin{abstract}
The Story of An Hour has always been regarded as the representative work of the American writer Kate Chopin. Concise in its language, the novel mainly describes the psychological changes and emotional experience of Mrs. Mallard after she was informed of her husband's death. Since its publication, relative research on the work has usually focused on the theme, expression and narrative strategy of the novel. Seldom finds that the use of signs, an inseparable part of the text has been applied skillfully to express the theme. Therefore, this study attempts to explore the symbolic meaning of hysterical screaming and cruel reality in The Story of an Hour by analyzing the use of signs under the theoretical framework of Peirce's Semiotics.
\end{abstract}

Keywords: The Story of an Hour; Peirce's semiotic theory; signs

\title{
Introduction
}

Written on April 19, 1894, and first published on December 6, 1894, under the title "The Dream of an Hour," one of Kate Chopin's most popular works was published in Vogue. The Story of An Hour tells the story around the news of Mr. Mallard's “death”, and mainly described Mrs. Mallard Louise's psychological process in one hour after hearing the news about her husband. It is this short and bittersweet journey that gives us a glimpse of the almost silent marriage life of married women in the 19th century. Through investigating into the use of signs with the help of Peirce's semiotic theory, a common female image and her internal desire for freedom and revolt against the traditional marriage and patriarchal norms at the end of the 19th century is revealed.

\section{Peirce's Semiotic Theory}

Charles Sanders Peirce (1839-1914) is one of the founders of modern semiotics. As the founder of American pragmatism and the leader of American science, he is also considered one of America's greatest philosophers, proficient in philosophy, logic, semiotics, linguistics, metrology, spectroscopy and other natural sciences. According to Peirce (1975), who has been trying to reveal the reasoning process of human thinking by researching signs:

"A sign, or representamen is something which stands to somebody for something in some respect or capacity It addresses somebody, that is, creates in the mind of that person an equivalent sign, or perhaps a more developed sign. The sign which it creates I call the interpretant of the first sign. The sign stands for something, its object not in all respects, but in reference to a sort of idea, which I have sometimes called the ground of the representamen." (p. 228).

In this sense, a sign is made up of three elements: sign, object and interpretant. Signs don't necessarily have to be linguistic signs, instead, they can be anything with their own special properties. As the main content that a sign refers to, an object can be something that can be discussed or thought about. At the same time, Peirce believes that an interpretant represents the relationship between a sign and its object, which is a kind of understanding. Its meaning can be broad enough.

Peirce further divides signs in terms of the relationship between a sign and its object, which including icons, indexes and symbols. Firstly, an icon also called "likeness" or "semblance" is a kind of sign which can be represented by similar images. An icon indicates its object by its own characteristics. Secondly, an index is also 
a kind of signs. An index is a "realistic correspondence" between a sign and its reference object. The relationship between it and the reference object is a fact. Thirdly, a symbol refers to the relationship between a sign and its object on the basis of social agreement. It is a particular kind of signs that works through association. For example, language signs are typical symbols.

With Peirce's semiotics as the methodology, the study of signs in literary work tends to be more comprehensive and in-depth, thus revealing the underlying meaning of The Story of an Hour. Peirce's semiotics can reveal the essence of things, and they should be able to provide a reasonable explanation of literary phenomena and give us a new tool to study signs even the whole literary problems.

\section{The Use of Icon in The Story of an Hour}

According to Peirce, an icon has a relation with its object by referring to its object which is similar in nature. He also called icons as "likeness" or "semblance". In other words, if we find that there is something in common between a sign and its object, it is called an icon. In The Story of An Hour, various icons are used to depict the character and themes. For example, the images of "the closed-door", "the open window", "bottom" of the stairs and some synaesthetic signs present us with two different worlds.

The space outside the closed door is the living room downstairs, in which all relatives and friends gather for social activities and Mrs. Mallard receives the news of her husband's death. It is in this space that her behaviour must correspond with the expectations of traditional ethical norms of the patriarchal society. After leaving all the people related to her husband and her previous life in the living room---her sister Josephine and her husband's friend Richards, Mrs. Mallard went back to her bedroom on the second floor alone, after the storm of grief. "She would have no one follow her." and sank into a "comfortable, roomy armchair". She needs to be alone, to examine the changes that this "bad news" will bring to her life. Her bedroom behind the door becomes the space of her fantasy of freedom and hope and a place of her secret inner world. The author describes in detail the awakening process of her awakening consciousness. Therefore, the sign of "closed-door" refers to a boundary between the private and public spheres, a dividing point between the old and the new life, and a barrier between the ideal and the reality.

The "open window" and some synaesthetic signs also play an important symbolic role in the process of awakening and growth of Mrs. Mallard's female consciousness. What she saw through the window was not scenery overcast with clouds and cold weather. On the contrary, it was a scene full of vigour and vitality in spring. She saw a new world outside the open window:

"She could see in the open square before her house the tops of trees that were all aquiver with the new spring life. The delicious breath of rain was in the air. In the street below a peddler was crying his wares. The notes of a distant song which some one was singing reached her faintly, and countless sparrows were twittering in the eaves" (p. 4).

The use of these synaesthetic signs, which symbolize "hope", "vitality" and "freedom", just shows the awakening of Mrs. Mallard's body and spirit. All her senses begin to perceive the beauty of life, and her most instinctive desire and appeal begin to wake up. When she was alone in the bedroom and look outside the open window, the use of these signs reveals that the seeds of self-consciousness, which had been repressed in her soul for a long time, began to sprout slowly. The open window gives Mrs. Mallard access to get contact with the future life. 
The "bottom" is the most ironic icon used in the novel. When Mrs. Mallard opened the door at the request of her sister Josephine and was "drinking in a very elixir of life through the open window", Richard was "waiting for them at the bottom". If the "open window" symbolizes the life full of "freedom" and "vitality", then the "bottom" symbolizes the "death", "despair" and "end" of the fantasy of a happy life. At this point, the ironic effect of the novel is perfectly integrated with the theme of "life" and "freedom" in the novel, which brings an end to the novel and leaves a sharp contrast between the hysterical screaming and cruel reality in readers' mind.

\section{The Use of Index in The Story of an Hour}

An index is a direct causal or proximity relationship between a sign and its object. This makes its object always a definite physical object or event associated with time and space. In The Story of An Hour, the protagonists' names, which serve as "index" to directly refer to different characters, are of great symbolic meanings.

According to the dictionary, "mallard" is named after its male physiological characteristics. American biologists found that mallard has the habit of controlling part of the brain to keep sleep and part of the brain to keep awake. This habit of half-asleep and half-awake can help them escape from the predation of other animals in a dangerous environment. To conclude, the main habits of mallard are summarized as follows: male dominates controls, brain consciousness, and is half-asleep and half-awake. Such an index symbolizes a male-dominated family---The Mallards. It is the epitome of male's dominant position, their control over women's thoughts and consciousness, and women's constant vigilance and prudence in the patriarchal society.

Besides, the name of the friend of Mrs. Mallard's husband ---"Richard" is also an index which means "ruler in power". This index refers to the traditional rules and ethical system of the patriarchal society, which is the most difficult area for Mrs. Mallard to breakthrough. When she wails and sips for her husband's death, Richard gives her an hour to be alone, not only because her previous performance conforms to what he thinks is "normal", but also to give other women an excellent sample. But even in this short hour, he was not at ease and sent Josephine upstairs, while he "stood downstairs waiting for them", showing his sensitivity and dedication. When "He stood amazed at Josephine's piercing cry", Richards responds with "quick motion to screen him from the view of his wife", acting calmly and quickly under this sudden change.

What's more, as Mrs. Mallard's sister, Josephine's name carries the meaning of "enhancement" and refers to a "prolific woman". It symbolizes those women who accept and obey the rules of fate and were deprived of the ability to think and were only accustomed to the dependent way of life. They believe that the greatest value of women's existence is "prolificacy", to have more children. When Mrs. Mallard went upstairs to be alone, a symbolic detail appears in the text:

"Josephine was kneeling before the closed door with her lips to the key hold, imploring for admission. 'Louise, open the door! I beg; open the door-you will make yourself ill. What are you doing, Louise? For heaven's sake open the door. ', (p. 6)

"Kneeling" is a gesture of absolute submission. Here Josephine kneels outside the "door" and performs Richard's will. She believes that staying alone inside is terrible, which "will make yourself ill". It's only normal and safe to open the door and return to the world with Richard. Though Richard didn't say a word, Josephine's language, behaviour and thought were highly consistent with him. Josephine, as a woman, could have been Louise's ally; as Louise's sister, she should have been Louise's staunch supporter. But the power of social 
contract goes beyond the natural ties of kinship and blood. Josephine finally stands in the opposite camp to Louise and cheers for the patriarchal society which suppresses women's freedom. From the signs of the names of Richard and Josephine, we can see that they unite together and form a big net to cover Mrs. Mallard firmly.

\section{The Use of Symbol in The Story of an Hour}

According to Peirce, a symbol is a kind of signs, which directs its object with the help of social convention. It is a particular kind of signs that works through association. It refers to the relationship between a sign and its object on the basis of social agreement.

In The Story of An Hour, Mrs. Mallard's "heart disease" is not a congenital biological disease. On the contrary, it is a kind of acquired physical and mental disease peculiar to women in the patriarchal society. It serves as a symbol for the tragic result for women who are indulged with an excessive obsession with abstract ideas such as individual freedom and self-assertion, regardless of individual social and moral norms. It also represents a kind of reflection on the ways and effectiveness of women's resistance and rethinking what is a good relationship between the two genders. In Madwoman in The Attic, Sandra M. Gilbert and Susan Gubar (2000) point out that

"Recently, in fact, social scientists and social historians like Jessie Bernard, Phyllis Chesler, Naomi Weisstein, and Pauline Bart have begun to study the ways in which patriarchal socialization literally makes women sick, both physically and mentally. Hysteria, the disease with which Freud so famously began his investigations into the dynamic connections between psyche and soma, is by definition a "female disease", not so much because it takes its name from the Greek word for womb, hyster (the organ which was in the nineteenth century supposed to "cause" this emotional disturbance), but because hysteria did occur mainly among women in turn-of-the-century Vienna, and because throughout the nineteenth century this mental illness, like many other nervous disorders, was thought to be caused by the female reproductive system, as if to elaborate upon Aristotle's notion that femaleness was in and of itself a deforrnity” (p. 53)

"Knowing that Mrs. Mallard was afflicted with a heart trouble, great care was taken to break to her as gently as possible the news of her husband's death.” (p. 1) This is the first sentence of the novel. Chopin's design of the plot can be described as extremely unique. Throughout the full text, it is not difficult to find that the dramatic irony formed by the dynamic interaction between Mrs. Mallard's "heart disease" and her husband's "death" not only promotes the development of the plot but also reveals the author's profound thoughts on gender relations.

At the end of the story, Mr. Mallard's return directly leads to Mrs. Mallard's sudden death, forming a rather intriguing contrast between the beginning and the end, which forms a perfect circle in the whole story. This kind of plot setting makes us ponder: in the relationship between the two genders, does one group's existence and development have to be at the cost of the other group's submission and even death? Can both co-exist and prosper together? The description of the extreme mentality of Mrs. Mallard reveals that excessive obsession with abstract ideas such as individual freedom and self-assertion, regardless of individual social and moral dimensions, will only lead to the extreme of doctrines and fall into the trap of madness out of touch with reality. In The Story of An Hour, Chopin tells a seemingly feminist story from the perspective of Mrs. Mallard. However, if we push it further, we will find that Chopin's vision includes not only the situation of women as a vulnerable group under the patriarchal system but also the situation of men who are closely related to the fate of women. 
What's important is not the confrontation between the two genders, but the relationship and association between them. The recognition of the common destiny of men and women is also one of the charms of Chopin's works.

\section{Conclusion}

Once published, The Story of An Hour has turned into the focus of criticism because of its exquisite language, simple structure and pungent irony. At the same time, the sensitive social topics such as "feminism", "freedom and self" and "marriage" involved in the novel make it more attractive. As a master of the novel, Kate Chopin uses different kinds of signs in the story, which greatly unifies the artistic skills and ideological meanings. This study aims to investigate the use of signs with the help of Peirce's Semiotic Theory. It finds out that a common female image and her internal desire for freedom and revolt against the traditional marriage and patriarchal norms at the end of the 19th century were depicted. It reveals that the tragedy of the heroine is not only the tragedy of women but also the tragedy of all human beings in the shrinking and disappearing living space under the restriction of social norms.

\section{References}

[1]. Charles S Peirce. (1975). The collected papers of Charles Sanders Peirce. Cambridge: Harvard University Press.

[2]. Kate Chopin. (2014). The Story of an Hour. Toronto: HarperCollins Canada.

[3]. Sandra M. Gilbert and Susan Gubar. (2000). The Madwoman in the Attic: The Woman Writer and the Nineteenth-Century Literary Imagination. Yale: Yale University Press. 